\title{
Revisiting Basaa verbal derivation
}

\author{
Emmanuel-Moselly Makasso \\ National Centre for Education - MINRESI, Yaoundé \\ E-mail: makasso2@gmail.com
}

\begin{abstract}
Basaa, a Narrow Bantu language (A43) spoken in Cameroon in Central Africa holds a serious record of descriptive works in phonology, morphology, and syntax. Verb morphology has been studied in detail by Bitjaa Kody (1990), Dimmendaal (1988), and Hyman (2003), among others. The present paper focuses on verb derivation in Baasa, and raises two main issues: (i) the paradigm of expansions that are recurrent in the language, and (ii) extensions which suggest the existence of additional suffixes to what is already reported. Further extensions include the perfective, the associative, and the tentive. This paper concludes with an attempt to reconstruct Basaa extensions, mirroring Schadeberg's (2003) Proto-Bantu propositions.
\end{abstract}

Keywords: Basaa; morphological expansion; perfective; associative; tentive

\section{Introduction}

The aim of this paper is to demonstrate how verbs are constructed in Basaa (6àsàá), a Narrow Bantu language (A43) spoken in Cameroon. Verbal derivatives have been examined in previous studies, e.g., Bitjaa Kody (1990), Dimmendaal (1988), Hyman (2000, 2003), and Voorhoeve (1980), among others.

Basaa verb stems, as in many other Bantu languages, are a combination of the lexical root and one or two extensions. The structure of the verbal stem is thus: [RADICAL - (EXPANSION) EXTENSIVE SUFFIX]. The final vowel has dropped out in most words in this language. Two aspects of Baasa verb morphology are studied here: morphological expansion and extensions.

The structure of the paper is as follows: in section 2, an overview of Baasa phonology is presented. Section 3 is devoted to morphological expansion, and section 4 to extensions. ${ }^{1}$

\footnotetext{
${ }^{1}$ In this paper, the IPA phonological transcription format is followed. For those who are familiar with Baasa data, we have the following correspondences (in bold): $/ \mathrm{p} /$ or $/ \mathrm{b} / \rightarrow / \Phi /$ or $/ \boldsymbol{\beta} / ; / \mathrm{t} /$ or $/ \mathrm{d} / \rightarrow / \mathrm{r} / ; / \mathrm{k} /$ or $/ \mathrm{g} / \rightarrow / \chi /$ or $/ \mathrm{y} / ; / \mathrm{y} /$ $\rightarrow / \mathbf{j} / ; /$ ny $/ \rightarrow / \mathbf{j} / ; / \mathbf{j} / \rightarrow / \mathbf{d} \mathbf{z} / ; / \mathrm{c} / \rightarrow / \mathbf{f g} / ; / \mathrm{VV} / \rightarrow / \mathrm{V}: /$.
} 


\section{Overview of phonology}

Basaa phonology is complex enough, with several rules which take the verb stems some time to respect cyclicity given a sound internal hierarchy, without neglecting the templatic and largely concatenative nature of the morphology (Hyman 2000, 2007). The following rules and processes have been accounted for in Basaa: Vowel Height Harmony (section 2.1), toneless suffixes (section 2.2), syncope (section 2.3), and phonotactics (section 2.4).

\subsection{Vowel Height Harmony}

This process appears only in verbal forms in the context of extension. As Schmidt (1994), followed by Mutaka and Bitjaa Kody (2000), and Sandy (2012) for Abo (A42), point out, Vowel Height Harmony (hereafter VHH) is a process by which the vowel of the verbal stem changes its aperture to a higher level, triggered by the extensive suffix that is added to it. It is important to note that not all the extensions are involved in this process.

$\begin{array}{lllll} & \text { tèn } & \text { 'to tie' } & \text { hór } & \text { 'to bend' } \\ \text { Reversive } & \text { tìn-ìl } & \text { 'to detach' } & \text { húr-ûl } & \text { 'to unbend' } \\ \text { Stative } & \text { tìn-1́ } & \text { 'being tied' } & \text { húr-1́ } & \text { 'being bent' }\end{array}$

\subsection{Toneless suffixes}

Apart from the stative suffix, which bears a H(igh) /- í, all the remaining suffixes are toneless. They connect in three phases to the verbal root:

i. $\quad$ They connect to the root and take a default $\mathrm{L}$ (ow);

ii. High tone spreading (HTS) when the root is $\mathrm{H}$;

iii. HTS is blocked when as a result of derivation; there are then two consonants in a row following the root.

(2)

\begin{tabular}{|c|c|c|c|}
\hline tèn & 'to tie' & hé $\chi$ & 'to block' \\
\hline à tìn-í & 'she is tied' & à híy-í & 'she is blocked' \\
\hline |j-ìl & 'to untie' & híy-îl & 'to unblock' \\
\hline n-nà & ‘to attach e.o.' & héy-nà & ‘to block e.o.' \\
\hline h-yà & 'to cause s.o. to tie' & híh-yà & 'to cause s.o. to block' \\
\hline
\end{tabular}

\subsection{Syncope}

Work by Hyman (2000) reveals an active process taking place in Basaa, by which the second vowel in a (C)VCVCV sequence is deleted. Due to the vowel deletion process $\left(\right.$ V.C. ${ }_{1} V \cdot C_{2} \mathrm{~V} \rightarrow$ $\left.\mathrm{VC}_{1} . \mathrm{C}_{2} \mathrm{~V}\right)$, two consonants become adjacent across syllable boundaries.

$$
\begin{array}{lll}
\text { sèßèl } & \text { 'to call' } & \text { nùyùr } \\
\text { sèß.l-à 'to tear' } & \text { 'to be called' } & \text { jùy.r-à }
\end{array}
$$

\subsection{Phonotactics}

When the habitual suffix /-a/ is added to a CVC root, syllabification into a CV.CV structure takes place. Basaa does not admit vowel clusters such as diphthongs. The language tolerates 
long vowels, but not two different vowels in a row. One strategy to repair ill-formed sequences is to introduce glides.

$\begin{array}{lllll}\text { lò } & \text { 'to lie' lòyà } & \text { 6ám } & \text { 'to shout at' } & \text { bámâ } \\ \text { sì: } & \text { 'to ache' sì-j-à } & \text { lù: } & \text { 'to immerse' } & \text { lù-w-à } \\ \text { hè: } & \text { 'to cut' hè-j-à } & \text { lò: } & \text { 'to surpass' } & \text { lò-w-à }\end{array}$

\section{Formal expansion}

In some cases, expansions may be identical to extensive suffixes, but the difference lies in the fact that the preceding syllable either has no lexical meaning or has lost it. This phenomenon is referred to in the literature as a "cranberry morpheme". Basaa displays four different expansions: \#ra, \#le, \#la, and \#re.

(5) Expansion with \#ra

$\begin{array}{llll}\text { hòy\#rà } & \text { 'to become muddled' } & \text { này\#rà } & \text { 'to go bad' } \\ \text { tíß\#rà } & \text { 'to soak sth.' } & \text { kwàyrà } & \text { 'to scrawl' } \\ \text { júß\#nà } & \text { 'to lose one's head' } & \text { tèy } & \text { 'to have the giggles' }\end{array}$

When drawing a semantic generalisation of the stems presented above, one can see the general theme of unsteadiness. These stems are all action predicates.

(6) Expansion with \#lع
غ́mb\#lı̀ 'to listen'
pé $\beta \# l \grave{\varepsilon} \quad$ 'to spy'
hém\#lè 'to believe' ḑù $\beta \# l$ '̇̀ 'to clean around crops'

No semantic generalisation can be made of the stems presented above in (6). These are concrete as well as abstract predicates.

(7) Expansion with \#la

$\begin{array}{llll}\text { sàmblà } & \text { 'to hug', } & \text { pàßlà } & \text { 'to hurry' } \\ \text { pùßlà } & \text { 'to hurry' } & \text { sčhlà } & \text { 'to tremble' }\end{array}$

No semantic generalisation can be made of the stems presented in (7), as with the case of expansions with \#le.

(8) Expansion with \#rغ̀

\begin{tabular}{|c|c|c|c|}
\hline kóß\#rè & 'to nail' & síß\#rغ̀ & 'to deal s.o. a blow' \\
\hline$\hat{n}=\#$ rè & 'to rub' & sùy\#rè & 'to shake' \\
\hline hóy\#rè & 'to climb' & & \\
\hline
\end{tabular}

\section{Verbal extensions}

This section on verbal extensions goes a little beyond the work on verbal morphology presented in Hyman (2003) and Bitjaa Kody (1990). The following extensions will be discussed: 
applicative, causative, reflexive, passive, perfective, habitual, stative, reciprocal, reversive, concomitant, tentive ${ }^{2}$, and antipassive.

\subsection{Applicative}

The applicative extension involves the action of being applied on behalf of, towards, or with regard to some object (Lodhi 2002). In the perspective of semantic roles, applicative verbs are expected to play the roles of beneficiary, place, time, cause, reason, and instrument.

\subsubsection{Beneficiary}

The beneficiary role is the most productive. The forms of the beneficiary are the following, depending on the form of the root:

\begin{tabular}{|c|c|}
\hline Root structure & Form \\
\hline V, V:, VC, CV, CV:, CVC & /-Vl/ (VHH) \\
\hline CV:, VCV, CVCV, CV:CV & /-ne/, /-na/ \\
\hline CVCVC & $/-\varepsilon /$ \\
\hline
\end{tabular}

(9)

Verb
é
j̀
$\grave{\varepsilon}:$
ámb:
àr
ò
c̀yg
jí
djé
jò̀
bèmb

Gloss

'to cut grass'

'to germinate'

'to cry'

'to make traps'

'to glue'

'to curse'

'to clothe'

'to know'

'to eat'

'to take'

'to wait'

\section{[Verb] for}

îl
òl
è:l
émb-êl
èr-èl
òy-òl
èng-èl
jîl
djêl
jòn-òl
bèmb-èl

From the stems presented in (9) above, it is evident that all are monosyllabic, and VHH applies as a rule. But there is an exception with two verbs, presented in (10), that do not apply VHH per se. There is no phonological explanation for the behaviour of these vowels.

$$
\begin{array}{llll}
\text { kè } & \text { 'to go' } & \text { kìl } & * \text { kèl } \\
\text { jè } & \text { 'to defecate' } & \text { jìl } & * \text { nèl }
\end{array}
$$

\footnotetext{
${ }^{2}$ What is reported as imperfective (with the $/-\mathrm{V} \chi /$ suffix) in previous works on the language will not be considered as an extension in this work, since this imperfective is inflectional. Examples are:

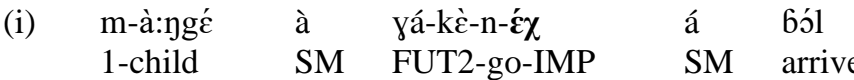

'After a long walk, the child will reach his destination.'

$\begin{array}{lll}\text { (ii) à } & \text { m̀-mál-à } \quad \text { bé duć } \\ & \text { 3SG PST1-finish-IMPNEG } & \text { eat } \\ \text { 'She has not yet finished eating.' }\end{array}$
}


The case is different when we move to disyllabic stems, where the suffix form is /-ne/ for open final syllables.

\begin{tabular}{|c|c|c|}
\hline hû: & 'to go back' & hú:-nغ̀ \\
\hline sò: & 'to hide' & sò:-nc̀ \\
\hline ò $\beta \grave{~}$ & 'to get spoiled' & ò $\beta-n \dot{\varepsilon}$ \\
\hline úmbê & 'to pour' & úmb-nè \\
\hline úl $\hat{\varepsilon}$ & 'to do sth. early' & púl-nè \\
\hline èng & 'to look at' & 6èng-nè \\
\hline
\end{tabular}

The data in (11) above display an application of syncope. When the stem is VCV, CVCV, or CVVCV and its final vowel is /a/, the suffix for the beneficiary will be /-na/ rather than /-ne/, as illustrated in (12).

$\begin{array}{lll}\text { éßâ } & \text { 'to show' } & \text { é } \beta \text {-nà } \\ \text { ùndà } & \text { 'to show' } & \text { ùnd-nà } \\ \text { jèyà } & \text { 'to greet' } & \text { jèy-nà } \\ \text { té:rà } & \text { 'to keep' } & \text { té:rà-nà } \\ \text { sí:rà } & \text { 'to suffer' } & \text { sí:rà-nà }\end{array}$

However, there are some exceptions, presented in (13), with certain stems failing to apply the rule for reasons that are unclear.

$$
\begin{array}{llll}
\text { wâ: } & \text { 'to be tired' } & \text { wê: } & * \text { wá:nc̀ } \\
\text { hô: } & \text { 'to get drunk' } & \text { hû: } & \text { *hó:nغ̀ }
\end{array}
$$

The third category of stem is CVCVC. It forms the beneficiary through the association of $/-\varepsilon /$ to the root, as is evident in the data presented in (14).

$$
\begin{aligned}
& \text { búyûl 'to masticate' búyl-è } \\
& \text { jàyàl 'to pray' jàyl-c̀ } \\
& \text { páhâl 'to confess' páhl-غ̀ }
\end{aligned}
$$

There are two monosyllabic verbs that behave like CVCVC:

$$
\begin{array}{lll}
\text { óm 'to send' } & \text { óm-l-è } \\
\varepsilon \dot{\varepsilon} \phi & \text { 'to send' }
\end{array}
$$

We can then have a sentence like:

$\begin{array}{llll}\text { m-à:ngé à } & \text { ̀̀-óm-1-ć } & \text { ń-!sáy } & \text { kà:r } \\ \text { 1-child SM } & \text { P1-send.APPL } & 1 \text {-father } & \text { 9book } \\ \text { 'The child sent a letter to his father, } & \end{array}$

\subsubsection{Place, time, cause, and reason}

The applicative stems in the categories of place, time, cause, and reason behave phonologically like the beneficiary that we have seen above. The table presented in section 4.1.1, repeated here, is applicable to these stems. 


\begin{tabular}{|c|c|}
\hline Root structure & Form \\
\hline V, V:, VC, CV, CV:, CVC & /-Vl/ (VHH) \\
\hline CV:, VCV, CVCV, CV:CV & /-ne/, /-na/ \\
\hline CVCVC & $/-\varepsilon /$ \\
\hline
\end{tabular}

(17)
m-ùră: à ǹ-lél-él í séyà
1-woman SM PST1-sleep.APPL LOC Eseka

'The woman spent the night in Eseka.'

$\begin{array}{lllll}\text { à } & \text { ǹ-sómb-ól } & \text { Bì-támb } & \text { í } & \text { 6òm } \\ \text { 3SG } & \text { PST1-buy.APPL } & \text { 8-shoe } & \text { LOC } & \text { 7.market }\end{array}$

'She bought the shoes at the market.'

sŭylù ì ón.né lí-!kándá

9.school SM build.APPL 5-crossroads

'The school is located at the crossroads.'

\subsubsection{Applicative as instrument}

There are two forms to express the instrumental meaning of the applicative, namely /-na/ and /-Vl/. Unlike the other applicative structures specified above, the instrumental suffix /-na/ does not absolutely require the verb root to be disyllabic and end in $/-\mathrm{a} /$. There is no phonological context to sketch the distribution of one form or the other.

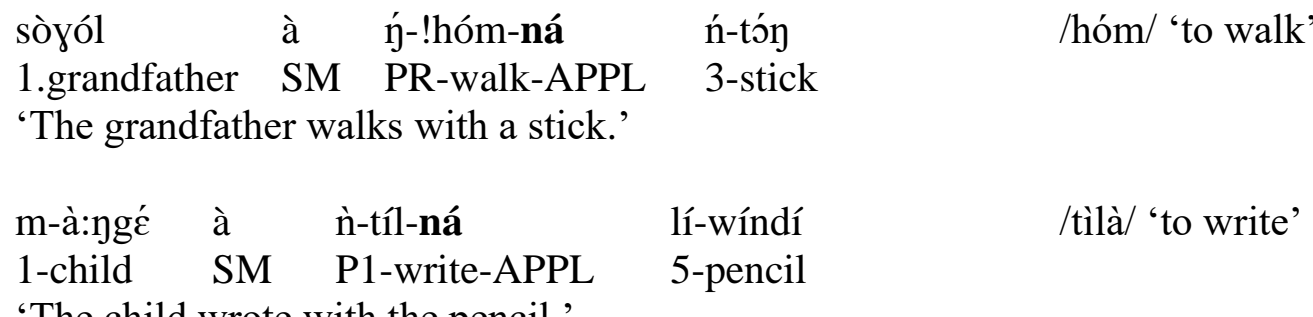

'The child wrote with the pencil.'

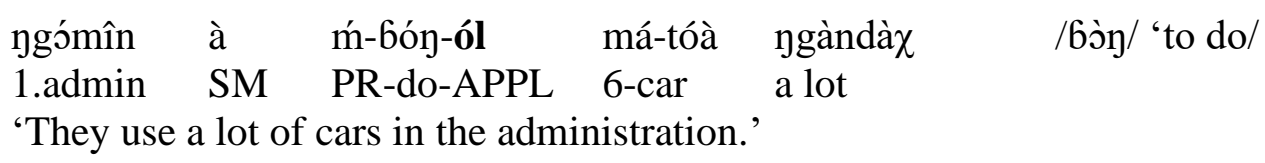

\subsection{Causative}

This extension expresses "cause to do" or "cause to be" (Lodhi 2002). In Basaa, there are two ways to express the causative: direct causative, on the one hand, is when the agent acts directly on the patient and obtains a change over his/her being or doing; indirect causative, on the other hand, is when the agent gets the patient him-/herself to change his/her doing or being.

As concerns the direct causative, the form is /-Vs/ $/-\mathrm{Vh} /$. The vowel of the suffix is a copy of that of the root, which is under the VHH constraint. One also has to consider that, in Basaa, there is free variation between [s] and [h] in utterance-final position (Makasso and Lee 2015). 
Concerning the group of verbs showing a change of state, the reflexive suffix brings across the nuance of "becoming". The process of derivation in this specific case is diversified with nominal (23a) as well as adjectival deverbatives (23b).

\begin{tabular}{|c|c|c|c|}
\hline $\begin{array}{l}\text { hìún } \\
\text { bé } \\
\text { mbó: }\end{array}$ & $\begin{array}{l}\text { 'anger' } \\
\text { 'ugliness' } \\
\text { 'health' }\end{array}$ & 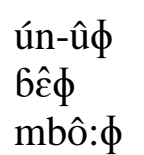 & $\begin{array}{l}\text { 'to get angry' } \\
\text { 'to become ugly' } \\
\text { 'to recover' }\end{array}$ \\
\hline $\begin{array}{l}\text { j̀kéní } \\
\text { hìsîî }\end{array}$ & $\begin{array}{l}\text { 'big' } \\
\text { 'small' }\end{array}$ & 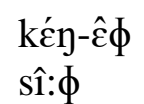 & $\begin{array}{l}\text { 'to put on weight' } \\
\text { 'to lose weight' }\end{array}$ \\
\hline
\end{tabular}

The third and last category implies that the action one is directing toward oneself is carried out with the help of someone or something. Unlike the two preceding categories, the verbs here are transitive. The suffix used here is $-6 a$.

\begin{tabular}{|c|c|c|c|}
\hline há & 'to put' & há- $\beta a ̂$ & 'to put on sth.' \\
\hline sj̀ & 'to wash' & sò- $\beta a ̀$ & 'to purge oneself' \\
\hline pám & 'to go out' & pám-bà & 'to succeed' \\
\hline tìlà & 'to write' & tìl-bà & 'to register' \\
\hline 1 & 'to turn’ & hèl-bà & 'to change into' \\
\hline
\end{tabular}

As we can see from the data presented in above (24), the bilabial implosive /6/ changes to the fricative $/ \beta /$ when immediately following a vowel. It may happen sometimes that the same verb gathers both categories of reflexive, resulting in two different meanings. That is the case with tèn 'to attach / to tie', which can be derived into tèy-è $\phi$ or tèn-6à.

$\begin{array}{lllllll}\text { m-à:ygè } & \text { à } & \text { ǹ-té!n-é } & \text { ní } & \text { dz-àm } & \text { lí } & \text { d\}é } \\ \text { 1-child } & \text { SM } & \text { PST1-tie-REFL } & \text { with } & \text { 5-thing } & \text { CONN } & \text { eat } \\ \text { 'The child is focused on food.' } & & & & \end{array}$

$\begin{array}{llll}\text { mùră: } & \text { à } & \text { ń-tèn-bá } & \text { lí-6àrò } \\ \text { 1woman } & \text { SM PR-tie-REFL } & \text { 5-wrap }\end{array}$

Furthermore, the reflexive suffix does not attach to stems with VCVC, CVCVC, or more such combinations. Therefore, to express the reflexive with long verbs, Basaa uses the pronoun /-mèr'́/ '-self' ${ }^{3}$ combined with the passive.

$\begin{array}{llll}\text { mà:ygé } & \text { à } & \text { ǹ-tíßl-á } & \text { jémèré } \\ \text { 1child } & \text { SM } & \text { PST1-treat-PASS } & \text { himself } \\ \text { 'The child treated himself.' } & \end{array}$

\subsection{Passive}

The passive form, in its cross-language definition, involves an agent acting upon a subject. That is, the agent in the subject position and the patient/theme in the object position exchange their

\footnotetext{
${ }^{3}$ The prefix of this pronoun concords with the head noun.
} 
positions. Basaa displays two suffixes for the passive, namely /-a / (VHH), presented in (27b), and /-6a / (VHH), in (27a). /-6a/ occurs when the verb ends in an open syllable.

\begin{tabular}{|c|c|c|c|c|}
\hline \multirow[t]{4}{*}{ a. } & djé & 'to eat' & dzé- $\beta a ̂$ & 'be eaten' \\
\hline & nó & 'to drink' & nó- $\beta a ̂$ & 'be drunk' \\
\hline & 6î: & 'to get married' & 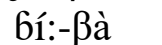 & 'be married' \\
\hline & kòndè & 'to add' & kònd-bà & 'be added' \\
\hline \multirow[t]{4}{*}{ b. } & sómb & 'to buy' & sómb-â & 'be bought' \\
\hline & l'́s $\phi$ & 'to throw away' & lé $\beta-\hat{a}$ & 'be thrown away' \\
\hline & tíßîl & 'to heal' & tíß.1-à & 'be treated' \\
\hline & tòmòl & 'to nail' & tòm.l-à & 'be nailed' \\
\hline
\end{tabular}

\subsection{Positional (stative)}

The positional or stative extension (Posit) implies that the subject is, at that moment, tied with a certain position or posture, and that position is likely to be durational (Lodhi 2002). This extension concerns only positional verbs. The suffix for the positional is /-i/l (VHH). VHH here is not automatic and does not concern disyllabic roots. When the verb root ends with an open syllable, there is an epenthetic /-1-/ that prevents two vowels becoming adjacent.

\begin{tabular}{|c|c|c|}
\hline nìn & 'to lie down' & nìn-1́ \\
\hline èn & 'to sit down' & jü: \\
\hline sér & 'to tilt' & sér-í \\
\hline tèn & 'to tie' & tìn-1́ \\
\hline jónd $\hat{\varepsilon}$ & 'to crouch' & nónd-í \\
\hline 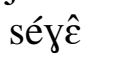 & 'to hang' & séy-í \\
\hline pèngè & 'to insert' & pèng-í \\
\hline & 'to cover' & hú-l-1́ \\
\hline òò & 'to hide' & sò-1-1 ${ }^{4}$ \\
\hline
\end{tabular}

Another distinguishing trait of this extension is that it involves no additional inflectional preverbal morpheme (TAM). Unlike other extensions that involve inflection, the positional already holds the inflection. The suffix /-í/ attaches directly to the root and it appears only on disyllabic verb stems.

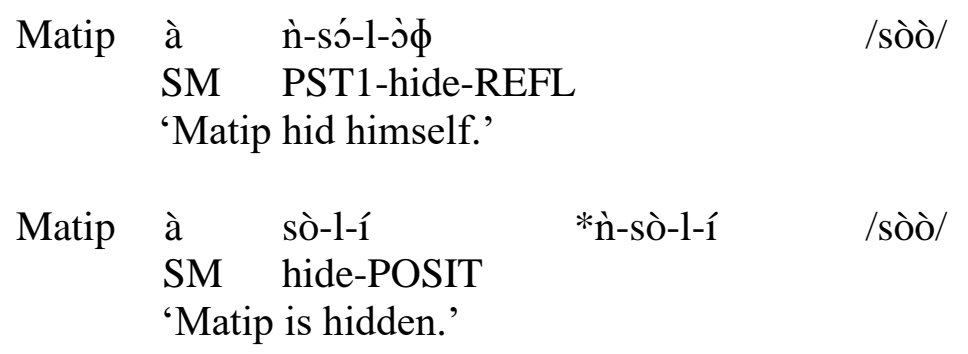

\footnotetext{
${ }^{4}$ In the case of both verbs, the epenthetic /-1-/ may be somewhat lexical. In one case, we have the reversive form hú-1-ûl 'to discover' already containing this consonant. For the second case, we have the nominal lì-sj̀l 'the act of hiding', where the epenthetic/-1// may have been deleted over time.
} 


\subsection{Perfective}

To my knowledge, no previous studies on Basaa mention the perfective extension at all. We have realised that Basaa has a form to indicate that an action has been carried out to completion. The suffix for this extension is /-i/ (VHH). The perfective suffix is toneless, while the stative is $H$. Furthermore, due to the difference in the inherent aspect of verbs for both categories, the verbs that take a stative suffix cannot take a perfective suffix. VHH does not apply to disyllabic verbal roots and, as one would expect, verbs with perfective extensions are intransitive. Consider the following examples:

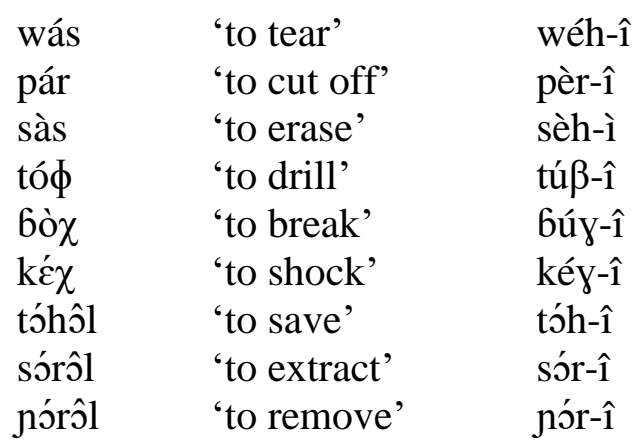

(31) à ̀̀̀-pér-î

3SG PST1-tear up-PERF

'She's deceased.'

$\begin{array}{llll}\text { kòò ú } & \text { ń-tú } \beta-1 ́ & \text { báskò } \\ \text { 3.tyre SM } & \text { PST1-hole-PERF } & \text { 7.bicycle } \\ \text { 'The bicycle has a flat tyre.' } & \end{array}$

\subsection{Habitual}

The habitual extension demonstrates a tendency or practice that is settled or regular, by which someone is recognised (Lodhi 2002). The meaning is something like "she used to ...". Verbs with the habitual extension can be transitivized or not. The form to mark habitual is /-a/, or /-na/ for vowel-final roots. In the case of long verb roots like CV:CV or CVCCV, the /-a/ of the suffix overrides the final vowel of the root.

\begin{tabular}{|c|c|c|}
\hline dzé & 'to eat' & d’źc-nâ \\
\hline há & 'to give' & há-nâ \\
\hline wás & 'to tear' & wáh-â \\
\hline sàs & 'to erase' & sàh-à \\
\hline tóhôl & 'to save' & tóhl-à \\
\hline sórôl & 'to extract' & sórl-à \\
\hline sì: & 'to ache' & sì-j-à \\
\hline lu: & 'to immerse' & lù-w-à \\
\hline l'́: & 'to receive' & lé:yà-nà \\
\hline nò:rغ̀ & 'to test' & nò:rà-nà \\
\hline
\end{tabular}




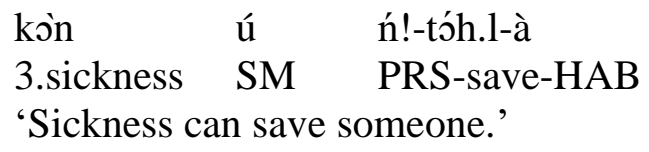

\subsection{Reversive}

The reversive extension is meant to reverse the meaning of the root onto its semantic opposite. This extension is not highly productive and it gives way to transitive stems. The form is /-Vl/ (VHH), the same as that of the applicative. The vowel of the suffix will be a copy of that of the root, provided that it has undergone $\mathrm{VHH}$.

\begin{tabular}{|c|c|c|}
\hline jì $\phi$ & 'to close' & $\mathrm{ji} \beta-\mathrm{ill}$ \\
\hline tèn & 'to tie' & tìn-ìl \\
\hline bòn & 'to do’' & 6ว̀y-ว̀l \\
\hline hé $\chi$ & 'to block' & híy-îl \\
\hline hó & 'to cover' & hù-1-ûl \\
\hline hùù & 'to inhume' & hù-l-ùl \\
\hline
\end{tabular}

\subsection{Associative}

This form indicates that the action is reciprocated or done "to one another". This extension, also referred to as the "reciprocal" (Ashton 1944), implies a plural subject (as from two subjects). The form that marks the associative is the suffix /-na/. When we have a long verb root like $\mathrm{CV}: \mathrm{CV}$ or $\mathrm{VCCV}$, the /-a/ of the suffix overrides the final vowel of the verbal stem. In (35) below, the forms in the column to the right denote "to [verb] each other".

\begin{tabular}{|c|c|c|}
\hline jí & 'to know’ & jí-nâ \\
\hline n'́ $\chi$ & 'to ignore' & né \\
\hline kàl & 'to say' & kà:-nà \\
\hline pònà & 'to resemble' & pò:-nà \\
\hline 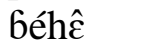 & 'to warn' & Géh-nà \\
\hline દ́mblè & 'to listen' & ćmblà-nà \\
\hline só:hغ̀ & 'to beg' & só:hà-nà \\
\hline nć: $\beta \grave{\varepsilon}$ & 'to accept' & né:ßà-nà \\
\hline nò:rè & 'to taste' & nว̀:rà-nà \\
\hline sòmbòl & 'to want' & sòmbl-à-nà \\
\hline hóyôl & 'to remind' & hóyl-à-nà \\
\hline
\end{tabular}

It is important to note that, along with the associative meaning "[verb] to one another", there is another sense of reciprocity among or between entities. The idea here is that of sharing.

\begin{tabular}{|c|c|c|c|}
\hline bà-lêr & bá & ßí-kàß-ná & pém \\
\hline 2-teacher & SM & PST2-divide-AS & 9.chalk \\
\hline \multicolumn{4}{|c|}{ 'The teachers shared chalk.' } \\
\hline 6-j̀:ngé & bá & ḿ-6éy-ná & mbâs \\
\hline 2-child & SM & PST1-cut-ASS & 9.maize \\
\hline
\end{tabular}

'The children shared maize.' 
rì-lóyá rí-bâ: rí j̉-kír-ná bíjê

13-boy 13-two SM PST1-cut-ASS 7.beer

'Two boys shared a beer.'

$\begin{array}{llll}\text { bà-lêr } & \text { bá } & \text { ßí-kà:-ná } & \text { má-líyá } \\ \text { 2-teacher } & \text { SM } & \text { PST2-say-ASS } & \text { 6-truth } \\ \text { 'The teachers told each other the truth.' } & \end{array}$

\subsection{Concomitant/contemporaneous}

The concomitant extension is highly productive in Basaa and involves the action being predicated by the verb and occurring at the same time as a similar event by another agent, e.g., "the train arrives at the same time as the bus". The form of the concomitant is the post-radical suffix /-ha/ (VHH) - the same reflex as for the indirect causative.

\begin{tabular}{|c|c|c|}
\hline kغ̀ & 'to go' & kì-hà \\
\hline lò & 'to come' & lò-hà \\
\hline hû: & 'to go back' & hú:-hà \\
\hline kòs & 'to receive' & kù:-hà \\
\hline kàl & 'to say' & kèh-là \\
\hline 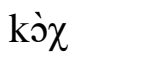 & 'to grind' & kòh-yà \\
\hline sèßèl & 'to call' & sèß1-à-hà \\
\hline nò̀̀rè & 'to test' & nò̀̀rà-hà \\
\hline sòmbòl & 'to want' & sòmbl-à-hà \\
\hline hónôl & 'to remind' & hónl-à-hà \\
\hline
\end{tabular}

As with the associative, the concomitant/contemporaneous extension is only relevant when the subject is plural. Since the /-ha/ cognate is also used for the causative, a singular subject will automatically attract a causative meaning.

\begin{tabular}{|c|c|c|c|c|c|}
\hline mùr & à & ̀̀-hó & jl-á-há & m-án & ḑ-àm \\
\hline $1 \mathrm{man}$ & SM & PST & -remind-CAUS(indir.) & 1-child & 5-thing \\
\hline \multicolumn{6}{|c|}{ 'A man reminded his child of something' } \\
\hline & íbáà & bá & ý-hóyl-á-há & b-ón & b-á $\phi$ \\
\hline$-\operatorname{man}$ & two & SM & PST1-remind-CONC & 2-child & 2-POSS \\
\hline
\end{tabular}

'Two men remembered their children at the same time.'

\subsection{Tentive}

The tentive extension has not been accounted for in previous work on Basaa. The tentive (Schadeberg 2003), also referred to as the "contactive" (Meeussen 1967), involves the verbal stem containing semantic elements denoting actively making contact. In Basaa, there are two types of contact expressed through morphological means: psychological contact and physical contact. The form for psychological contact is /-ra/, while the form for physical contact is /- $6 \varepsilon /$.

$\begin{array}{llll}\text { nó } \chi & \text { 'to hear' } & \text { nóy-rà } & \text { 'to understand, to feel' } \\ \text { hè } & \text { 'to measure' } & \text { hèy-rà } & \text { 'to imagine' } \\ \text { lé } \phi & \text { 'to attach' } & \text { líß-rà } & \text { 'to tie' }\end{array}$




\begin{tabular}{|c|c|c|c|}
\hline 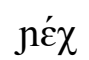 & 'to come close' & néy-rà & 'to jam’ \\
\hline & 'to be overfull' & pày-rà & 'to be over-busy' \\
\hline káф & 'to catch' & káß-rà & 'to understand' \\
\hline
\end{tabular}

The second category of stems refers to physical contact, implying geographical proximity between two entities. Some of the verbs are transitive correlates of the reversive category, which is intransitive. The distinguishing trait of this extension is that the meaning denotes contact.

\begin{tabular}{|c|c|c|c|}
\hline t'cl $l \hat{\varepsilon} \phi$ & 'to stand' & 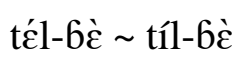 & 'to walk on sth.' \\
\hline & 'to lean back' & níj-bè & 'to lay one's back on' \\
\hline & 'to stick' & ár-bè & 'to be glued on' \\
\hline áxââ & 'to hang on' & sáy-6غ̀ & 'to catch on sth.' \\
\hline
\end{tabular}

There are also tentive extensions on verbs, which are not related to reversive extensions.

\begin{tabular}{|c|c|c|c|}
\hline pà $\chi$ & 'to be overfull' & pày-bغ̀ & 'to take hold of all, to invade' \\
\hline bán & 'to immobilise' & Gán-bè & 'to jump on s.o.' \\
\hline nùmb & 'to smell, to exhale' & nù:-mbغ̀ & 'to smell' \\
\hline & 'to cradle' & só:- $\beta \grave{\varepsilon}$ & 'to get stuck in mud' \\
\hline kذ̀ $\phi$ & 'to hitch sth. to' & kj̀:- $\beta \varepsilon \grave{\varepsilon}$ & 'to get stuck on' \\
\hline
\end{tabular}

\subsection{Antipassive}

In this section, I explore some data which show that the antipassive extension is at play in Baasa. According to Dixon (1994: 146), cited in Bostoen, Dom and Segerer (2015), a voice construction must meet the following four conditions to be considered antipassive:

(i) It must be a detransitivized construction;

(ii) The subject of the antipassive must correspond to the subject of the underlying active clause;

(iii) The object of the base verb must either fulfil an oblique function, being treated as a non-core argument, or be omitted;

(iv) There must be some overt formal marking, signalling an antipassive derivation.

In Basaa, the antipassive is expressed by the morphemes /-nà/ and /-à/, and this is evident with only two verbs, namely téh 'c 'to see' and nùn 'to look'.

(42) a. 6-ò:ngé bá ń-tćh-nà

2-child SM PST1-see-ASS

'The children saw each other.'

b. m-à:ngé à ń-!tćh-nà

1-child SM PR-see-ANTIPASS

'The child can see.'

c. m-à:ngé à ń-nùn-à

1-child SM PR-look-ANTIPASS

'The child can look.' 
From the example above, we can see that téh-nà in (42a) expresses an associative meaning the children looked at and saw each other. However, in (42b), the reading is not the same. Used in the singular, the idea of "having the capacity to see" is expressed, not the associative. Used in the plural, the sentence is ambiguous, as it can have both an associative and antipassive meaning. The case is almost similar with (42c), where the sentence expresses the idea of "having one's eyes open".

\section{Summary and discussion}

To sum up, the various extensions are presented in the following table:

\begin{tabular}{|c|c|c|c|c|}
\hline Extension & & Form & Productivity & Transitivity? \\
\hline \multirow{3}{*}{ Applicative } & Beneficiary & -Vl; -nc; -na & High & Yes \\
\hline & Place, time, reason & -Vl; -nc; -na & High & Yes \\
\hline & Instrument & -na & High & Yes \\
\hline \multirow{2}{*}{ Causative } & Direct & $-\mathrm{Vs} \sim-\mathrm{Vh}$ & High & Yes \\
\hline & Indirect & -ha & High & Yes \\
\hline \multicolumn{2}{|l|}{ Reversive } & $-\mathrm{V} 1$ & Limited & Yes \\
\hline \multirow{3}{*}{ Reflexive } & Direct & $-\mathrm{V} \phi$ & Limited & No \\
\hline & Change of state & $-\mathrm{V} \phi$ & Limited & No \\
\hline & Indirect & $-6 a$ & Limited & Yes \\
\hline \multicolumn{2}{|l|}{ Passive } & $-6 a ;-a$ & High & No \\
\hline \multicolumn{2}{|l|}{ Habitual } & $-a ;-n a$ & High & Yes \\
\hline \multicolumn{2}{|l|}{ Stative } & -1 & Limited & No \\
\hline \multicolumn{2}{|l|}{ Perfective } & $-\mathrm{i}$ & Limited & No \\
\hline \multicolumn{2}{|l|}{ Associative } & -na & High & Yes \\
\hline \multicolumn{2}{|l|}{ Concomitant } & -ha & High & Yes \\
\hline \multicolumn{2}{|l|}{ Tentive } & $-r a ;-6 \grave{\varepsilon}$ & Limited & Yes \\
\hline \multicolumn{2}{|l|}{ Antipassive } & -à; -nà & Very limited & No \\
\hline
\end{tabular}

An attempt to reconstruct the Basaa verb extensions leads to the conclusion that the reflexes, except the stative, in this language are somewhat close to the sounds suggested for both Proto-Bantu (Schadeberg 2003) and for Proto-Niger-Congo (Voeltz 1977), as presented in Hyman (2007):

\begin{tabular}{|l|c|c|c|}
\hline & Proto-Niger-Congo & Proto-Bantu & Basaa \\
\hline Applicative & $*_{\text {-de }}$ & $*_{\text {-Id- }}$ & -Vl; -na \\
\hline Causative & $*_{\text {-ci, } * \text {-ti }}$ & $*_{\text {-ic-i- }}$ & -Vs -Vh, -ha \\
\hline Contactive & $*_{\text {-ta }}$ & $*_{\text {-at- }}$ & -ra \\
\hline Passive & $*_{\text {-o }}$ & $*_{\text {ib-U- }}$ & - ba; -a \\
\hline Reciprocal & $*_{\text {-na }}$ & $*_{\text {-an- }}$ & -na \\
\hline Reversive (trans.) & $*_{\text {-to }}$ & $*_{\text {-Ud- }}$ & -Vl \\
\hline Reversive (intrans.) & $*_{\text {-ko }}$ & $*_{\text {-Uk- }}$ & -Vl \\
\hline Stative (neuter) & $*_{\text {-ke }}$ & $*_{\text {-Ik- }}$ & \\
\hline Stative (positional) & $*_{\text {-ma }}$ & $*_{\text {-am- }}$ & -í \\
\hline
\end{tabular}

A suggestion for future research, may be to analyse the interaction of phonological, morphological, and lexical information to make Grammar. 


\section{References}

Ashton, E.O. 1944. Swahili grammar (including intonation). London: Longman.

Bitjaa Kody, Z.D. 1990. Le Système Verbal du Basaa. Unpublished doctoral dissertation, University of Yaoundé.

Bostoen, K., S. Dom and G. Segerer. 2015. The antipassive in Bantu. Linguistics 53(4): 731-772. https://doi.org/10.1515/ling-2015-0016

Dimmendaal, G.J. 1988. Aspects du basaá. [Translated by L. Bouquiaux.] Paris: Peeters/SELAF.

Dixon, R.M.W. 1994. Ergativity. Cambridge: Cambridge University Press.

Hyman, L. 2000. Cyclicity and templatic morphology in the Basaa verb stem. Paper presented at the Second Round Table in Phonology of the GDR 1954, Bordeaux, 8 June 2000.

Hyman, L. 2003. Basaá (A43). In D. Nurse and G. Phillipson (eds.) The Bantu languages. London: Routledge. pp. 257-282.

Hyman, L. 2007. Niger-Congo verb extensions: Overview and discussion. In D.L. Payne and J. Pena (eds.) Selected proceedings of the $37^{\text {th }}$ Annual Conference on African Linguistics. Somerville, MA: Cascadilla Proceedings Project. pp. 149-163.

Lodhi, A. 2002. Verbal extensions in Bantu: The case of Swahili and Nyamwezi. Asia \& Africa No. 2: 4-26.

Makasso, E-M. and S. Lee. 2015. Basaa. Journal of the International Phonetic Association 45(1): 71-79.

Meeussen, A.E. 1967. Bantu grammatical reconstructions. Africana Linguistica 3: 79-121. https://doi.org/10.3406/aflin.1967.873

Mutaka, N.M. and Z.D. Bitjaa Kody. 2000. Vowel raising in Basaa verbal forms. Journal of West African Languages 28: 11-26.

Sandy, C. 2012, Verb Extensions in Abo (Bantu A42). Paper presented at the 43rd Annual Conference on African Linguistics, New Orleans, 15-17 March 2012.

Schadeberg, T. 2003. Derivation. In D. Nurse and G. Philippson (eds.) The Bantu languages. London: Routledge. pp. 71-89.

Schmidt, D.S. 1994. Phantom consonants in Basaa. Phonology 11: 149-178. https://doi.org/10.1017/s0952675700001871

Voeltz, E.F.K. 1977. Proto Niger-Congo Verb Extensions. Unpublished doctoral dissertation, University of California, Los Angeles.

Voorhoeve, J. 1980. La dérivation verbale en basaá. In L. Bouquiaux (ed.) L'expansion bantoue, vol. 2. Paris: SELAF. pp. 493-501. 